\title{
Sufentanil Citrate
}

National Cancer Institute

\section{Source}

National Cancer Institute. Sufentanil Citrate. NCI Thesaurus. Code C47731.

The citrate salt form of sufentanil, a synthetic congener of fentanyl and related to the phenylpieridines, with analgesic property. Sufentanil citrate binds to and activates the muopioid receptor, thereby producing analgesia, respiratory depression, miosis, reduced gastrointestinal motility, and euphoria. In addition, this agent has a more rapid onset of action and shorter duration of action compared to fentanyl. 